\title{
High performance enzymatic synthesis of oleyl oleate using immobilised lipase from Candida antartica
}

\author{
Salina Mat Radzi \\ Faculty of Science \\ Universiti Putra Malaysia \\ 43400 UPM Serdang, Selangor, Malaysia \\ Tel: 60389486106 ext 3615 / 3580 \\ Fax: 60389432508 \\ E-mail: salina_radzi@hotmail.com \\ Mahiran Basri* \\ Faculty of Science \\ Universiti Putra Malaysia \\ 43400 UPM Serdang, Selangor, Malaysia \\ Tel: 60389486106 ext 3615 / 3580 \\ Fax: 60389432508 \\ E-mail: mahiran@fssas.upm.edu.my
}

\section{Abu Bakar Salleh}

Faculty of Biotechnology and Biomolecular Sciences

Universiti Putra Malaysia

43400 UPM Serdang, Selangor, Malaysia

Tel: 603894867590

Fax: 60389467593

E-mail: abubakar@biotech.upm.edu.my

Arbakariya Ariff

Faculty of Biotechnology and Biomolecular Sciences

Universiti Putra Malaysia

43400 UPM Serdang, Selangor, Malaysia

Tel: 60389486101 ext 8090

Fax: 60389467593

E-mail: arbarif@biotech.upm.edu.my

\section{Rosfarizan Mohammad}

Faculty of Biotechnology and Biomolecular Sciences

Universiti Putra Malaysia

43400 UPM Serdang, Selangor, Malaysia

Tel: 60389467518

Fax: 60389467593

E-mail: farizan@biotech.upm.edu.my

\section{Mohd. Basyaruddin Abdul Rahman}

Faculty of Science

Universiti Putra Malaysia

43400 UPM Serdang, Selangor, Malaysia

Tel: 60389486106 ext 6798 Fax: 60389432508

E-mail: basyar@fsas.upm.edu.my

Raja Noor Zaliha Raja Abdul Rahman

Faculty of Biotechnology and Biomolecular Sciences

Universiti Putra Malaysia

43400 UPM Serdang, Selangor, Malaysia

Tel: 60389486101 ext 8090

Fax: 603-89423087

E-mail: mzaliha@fsas.upm.edu.my

Financial support: This project was financed by a grant from IRPA Project, No.01-02-04-0000-PR, Malaysia.

Keywords: Oleyl oleate, immobilised lipase, esterification, liquid wax ester.

\footnotetext{
* Corresponding author
} 
High performance enzymatic synthesis of oleyl oleate, a liquid wax ester was carried out by lipase-catalysed esterification of oleic acid and oleyl alcohol. Various reaction parameters were optimised to obtain high yield of oleyl oleate. The optimum condition to produce oleyl oleate was reaction time; $5 \mathrm{~min}$, organic solvents of $\log$ $P \geq 3.5$, temperature; $40-50^{\circ} \mathrm{C}$, amount of enzyme; 0.2 $0.4 \mathrm{~g}$ and molar ratio of oleyl alcohol to oleic acid; 2:1. The operational stability of enzyme was maintained at $>90 \%$ yield up to 9 cycles. Analysis of the yield of the product showed that at optimum conditions, $>95 \%$ liquid wax esters were produced.

Wax esters are an important class of fine organics that are widely used in cosmetic, pharmaceutical and lubricant industries (Wiling, 1996; Decagny et al. 1998; GomaDoncescu and Legoy, 1997; Mukerjee and Kiewitt, 1988; De et al. 1999). Special characteristics of non-toxicity, good fat soluble properties and excellent wetting behaviour at interfaces make them very special to be used in cosmetic formulations (cleansers, conditioners and moisturizers) (Peter and Robert, 2001). Natural wax ester can be extracted from animals and plant materials such as beeswax, sperm whale and jojoba oil. However, they are often in short supply and at present too expensive for commercial exploitation (Prapulla et al. 1992; Langrand et al. 1998).

Currently, most of the wax esters used commercially are of synthetic origin. They are generally produced by chemical reaction of an alcohol with an organic acid in the presence of an acid catalyst. The chemically synthesized product is cheap but not natural. The high-temperature process can lead to degradation of the esters and undesired side reactions; the resulting energy cost is high (Awang et al. 2003). To overcome this problem, enzymatic synthesis can be attractive as it is typically very selective and is performed at moderate temperatures and pressures. Esters produced through biocatalysis can be considered close to 'natural' and can potentially satisfy recent consumer demand (Gillies et al. 1987).

Biotechnology production of esters with lipases is important and lipase-catalysed reactions have recently received greater consideration over the traditional chemical synthetic methods. The use of lipases (triacylglycerol hydrolases, E.C. 3.1.1.3) to catalyse reactions in organic solvent is well documented (Akoh et al. 1992; Hari Krishna et al. 1999; Hari Krisha et al. 2000). One of the driving force for this research is the possibility of preparing a synthetic wax esters which resemble naturally occurring waxes of commercial interest. The specificity of the lipase to form an ester bond permits control of specific reactions which will also increase yield. There are many published papers on the catalytic performance of wax ester synthesis. However there are no reported work on high productivity (product/time) on the synthesis of wax ester.
A better understanding of various reaction parameters affecting the esterification with long-chain substrates is essential for possible large scale synthesis. This paper shows a high performance synthesis of oleyl oleate, by enzymatic synthesis route using an immobilised lipase from Candida antartica (Novozym 435) in organic solvents.

\section{MATERIALS AND METHODS}

\section{Materials}

Novozym 435 as 10,000 PLU (from Candida antartica lipase immobilised onto macroporous acrylin resin) was kindly donated from Novo (Malaysia). Oleyl alcohol (purity, $>60 \%$ ), oleic acid (purity, $>85 \%$ ) and authentic standard of oleyl oleate (purity, $>99 \%$ ) were obtained from Tokyo Kasei Kogyo Co., Ltd. (Japan). All other reagents were of analytical grade and used as received.

\section{Oleyl oleate synthesis}

The reaction system consisted of $2 \mathrm{mmol}$ of oleic acid, 4 mmol of oleyl alcohol, $2.0 \mathrm{ml}$ of hexane and $0.3 \mathrm{~g}$ of Novozym 435 . The mixture was incubated at $37^{\circ} \mathrm{C}$ using a horizontal waterbath shaker. The agitation speed was set at $150 \mathrm{rpm}$ and the reaction mixture was continuously reacted for $180 \mathrm{~min}$. The reaction was then terminated by dilution with $7.0 \mathrm{ml}$ of ethanol/acetone $(1: 1 \mathrm{v} / \mathrm{v})$.

\section{Identification of reaction product}

The product was periodically tested using thin layer chromatography, TLC (Merck type DC-plastic folein Keisel gel $\left.60 \quad \mathrm{~F}_{254}\right)$; Fourier Transform Infrared Spectroscopy, FTIR (Perkin Elmer, model 1650) and gas chromatography, GC (Hitachi, model G 3000). Preliminary detection and identification of reaction product were facilitated by TLC. The developing solvent system used was ethyl acetate:hexane:acetic acid (20:8.5:0.5, v/v). Further identification was carried out by FTIR. Final identification was performed by GC instrument equipped with a medium polar capillary column RTX-65-TG (Restek Corporation, USA). Helium was used as carrier gas at 1.0 $\mathrm{ml} / \mathrm{min}$. The initial column temperature was $150^{\circ} \mathrm{C}$ and the final temperature was set at $300^{\circ} \mathrm{C}$. The zone temperature for injector and detector were set at $330^{\circ} \mathrm{C}$ and $350^{\circ} \mathrm{C}$. The temperature was increased at $10^{\circ} \mathrm{C}$ per minute to $280{ }^{\circ} \mathrm{C}$, and then it was increased at $5^{\circ} \mathrm{C}$ per minute to the final temperature.

\section{Analysis of reaction product}

Determination of the percentage conversion of oleyl oleate (\%). The percentage conversion (\%) of oleyl oleate was measured by determining the remaining unreacted fatty acids in the reaction mixture by titration with $0.1 \mathrm{M} \mathrm{NaOH}$ in an automatic titrator (Radiometer, $\mathrm{ABU}$ 90). All the samples were assayed in triplicate and the experiment was repeated twice. 


\section{Volume of $\mathrm{NaOH}$ used (without enzyme)}

Effect of reaction time. The effect of time in the wax ester synthesis was investigated by varying reaction periods $(1$, $2,3,4,5,10,15,30,45,60,90,120,150$ and $180 \mathrm{~min})$ while fixing the other conditions. The percentage conversion was determined as described above.

Effect of various organic solvents. The reactions were studied using various organic solvents (benzene, $\log \mathrm{P}=2.0$; toluene, $\log \mathrm{P}=2.5$; hexane, $\log \mathrm{P}=3.5 ; \mathrm{n}$-heptane, $\log$ $\mathrm{P}=4.0$; nonane, $\log \mathrm{P}=5.1 ; \mathrm{n}$-hexadecane, $\log \mathrm{P}=8.8$ ) while fixing the other conditions. Percentage conversion of wax ester was determined as described above.

Effect of reaction temperature. The reaction mixtures were incubated at various reaction temperatures $(30,40,50$, 60 and $70^{\circ} \mathrm{C}$ ) while fixing the other conditions. Percentage conversion of wax ester was determined as described above.

Effect of amount of enzyme. The reactions were studied using various amount of enzyme (0.1, 0.2, 0.3, 0.4 and 0.5 g) while fixing the other conditions. Percentage conversion of wax ester was determined as described above.

Effect of molar ratio. The reaction mixtures were reacted with different molar ratio of substrates, mmol oleyl alcohol/ mmol oleic acid (molar ratio $=1,2,3,4$ and 5) while fixing the other conditions. Percentage conversion of wax ester was determined as described above.

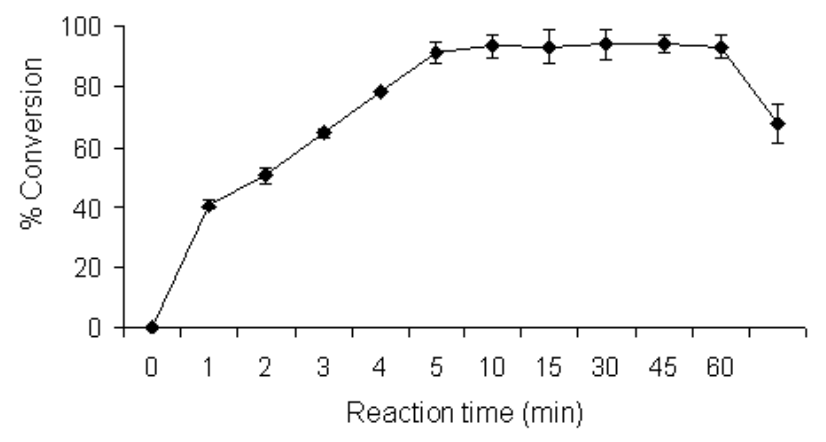

Figure 1. Effect of reaction time on the synthesis of oleyl oleate. Reaction condition: temperature, $37^{\circ} \mathrm{C}$; molar ratio of substrate (mmol oleyl alcohol/mmol oleic acid), 2:1; amount of enzyme, $0.3 \mathrm{~g}$; and agitation speed of $150 \mathrm{rpm}$.

Effect of heat on enzyme stability. Three types of Novozym 435 preparation were used in the reaction. They were fresh Novozym 435 , Novozym 435 heated at $50^{\circ} \mathrm{C}$ for $60 \mathrm{~min}$ and Novozym 435 incubated in hexane for $60 \mathrm{~min}$ at $50^{\circ} \mathrm{C}$ before being used for esterification reaction. Reaction conditions for the other parameters were followed as described above. The activity of Novozym 435 was assayed in term of percentage of conversion of oleyl oleate as described above.

Effect of enzyme reusability. After each cycle, the reaction mixture was removed and the Novozym 435 was rinsed with excess hexane, filtered and the solvent was evaporated under a stream of nitrogen before being used with fresh substrates. Reaction conditions for the other parameters were followed as described above. The activity of Novozym 435 was determined in term of percentage of conversion of oleyl oleate as described above.

\section{RESULTS AND DISCUSSION}

\section{Identification of reaction product}

Products from esterification reaction between oleic acid and oleyl alcohol catalysed by Novozym 435 were monitored by TLC. The presence of the oleyl oleate, oleic acid and oleyl alcohol were detected as brown spots when visualized by an iodine reagent. Further identification was carried out by FTIR showed a characteristic absorption of ester bond at $1742 \mathrm{~cm}-1$. Final identification of reaction mixture was performed by GC by comparing the ester with a known authentic standard. The profile of GC chromatogram showed major peak of oleyl oleate presence at retention time of $14.14 \mathrm{~min}$, oley alcohol at $3.54 \mathrm{~min}$ and oleic acid at $4.29 \mathrm{~min}$.

\section{Effect of reaction time}

Time course study gives an insight into the performance of an enzyme as the reaction progresses. Such progress curves help determine the shortest time necessary for obtaining good yield and so enhance cost-effectiveness of the process (Yee et al. 1997). The profile of wax ester produced at various time intervals is presented in Figure 1. The conversion of oleyl oleate was increased with increasing reaction time. Novozym 435 gave highest percentage yield within a reaction period of $5 \mathrm{~min}$. After $5 \mathrm{~min}(91.3 \%)$, the percentage yield was relatively constant. This may be due to the reactions having achieved the equilibrium. Similar finding was reported by Chen et al. 1995, although the esterification reaction used immobilised Rhizophus niveous fungal cells. The initial reaction rate was rather insensitive to the water produced, since little water was formed during the initial stage (Chen et al. 1995). The yields remained constant after $5 \mathrm{~min}$ of reaction may be due to the production of water molecule, which had increased in an adequate value to accommodate the hydrolysis process (Virto and Adlercreuz, 2000). 


\section{Effect of various organic solvents}

During the last decade, the tremendous potential of enzymes as practical catalyst for chemical processes in nonaqueous environments has been well recognized (Lozano et al. 2004). The use of biocatalyst in organic solvents offers many advantages over using pure water, such as the increase in solubility of poorly water-soluble organic substrates, avoiding unwanted side reactions and degradation of common organic reagents, as well as the ability to shift the thermodynamic equilibrium of many processes to the synthetic way, thus favouring product recovery (Klibanov, 1997). The polarity of the organic solvents employed for the esterification reaction is known to affect the enzyme activity (Hari Krishna et al. 2001). The $\log \mathrm{P}$ value of the solvents is widely used parameter to describe solvent polarity and their possible effect on enzyme activity where $\mathrm{P}$ is the partition coefficient of a given solvent between water and octanol in a two-phase system. It is generally recommended that the use of solvents with $\log \mathrm{P}>4.0$ (nonpolar) result in better esterification. Figure 2 shows the effect of various organic solvents on the Novozym 435 catalysed synthesis of oleyl oleate. Generally all the solvents showed high percentage yield especially with n-hexadecane $(93.2 \%)$ with $\log$ P 8.8 , followed by nonane $(92.1 \%)$ and hexane $(91.8 \%)$ with $\log$ $\mathrm{P}$ both 5.1 and 3.5 respectively. Other solvents with $\log \mathrm{P}$ $<3.5$ tend to give relatively lower esterification. This was probably due to the following reasons, (i) they enhanced dissociation of weak organic acid and built up the net proton concentration in the homogeneous phase, which led to the reverse reaction (hydrolysis), and (ii) they might also strip off the essential water around the enzyme present as microaqueous layer thereby, affecting the active conformation of the enzyme. Our observation are in agreement with the literature reports showing relatively lower ester conversions in solvents with $\log \mathrm{P}<2.5$ (Hari Krishna et al. 2001).

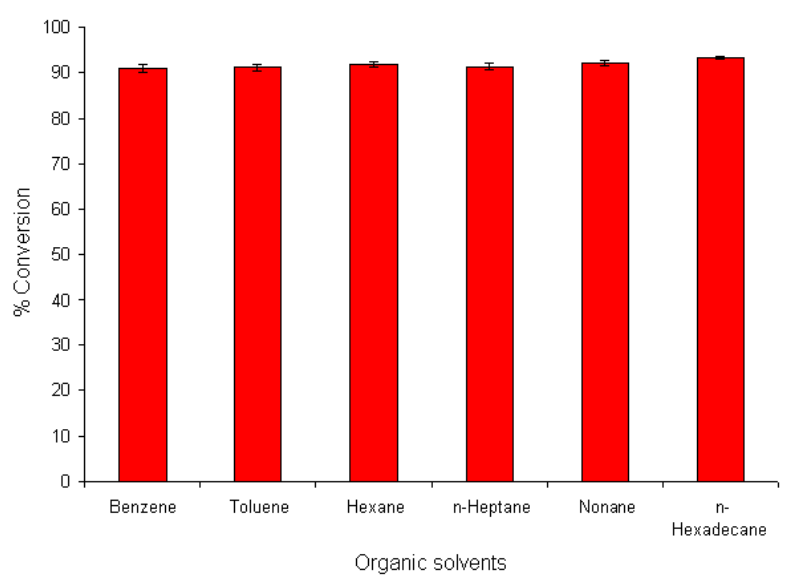

Figure 2. Effect of various organic solvents on the synthesis of oleyl oleate. Reaction condition: reaction time, $60 \mathrm{~min}$; temperature, $37^{\circ} \mathrm{C}$; molar ratio of substrate (mmol oleyl alcohol/mmol oleic acid), 2:1; amount of enzyme, $0.3 \mathrm{~g}$; and agitation speed of $150 \mathrm{rpm}$.

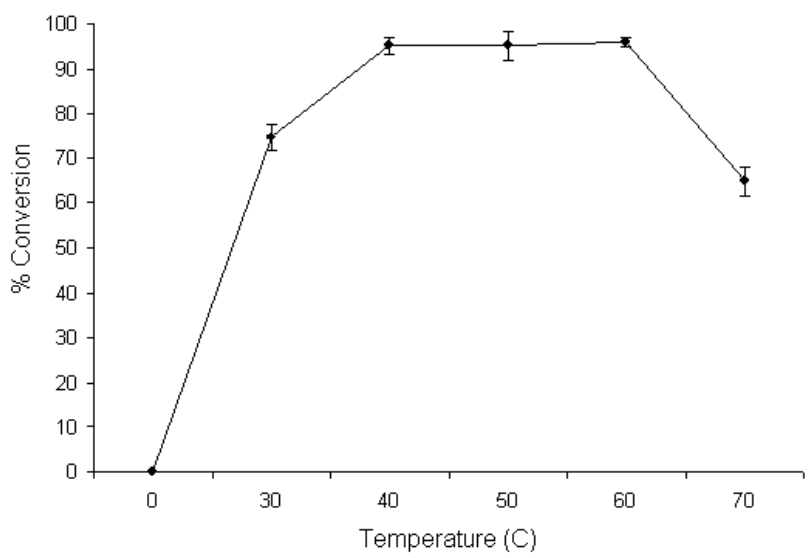

Figure 3. Effect of reaction temperature on the synthesis of oleyl oleate. Reaction condition: reaction time, $60 \mathrm{~min}$; molar ratio of substrate ( $\mathrm{mmol}$ oleyl alcohol $/ \mathrm{mmol}$ oleic acid), 2.1; amount of enzyme, $0.3 \mathrm{~g}$; and agitation speed of $150 \mathrm{rpm}$.

\section{Effect of reaction temperature}

The effects of reaction temperature can be apportioned to its effect on substrate solubility as well as its direct influences on the reaction and the enzyme (Facioli and Barrera-Arellano, 2001). Effect of reaction temperature on esterification reaction is shown in Figure 3. Initially, the percentage conversion of wax ester was increased with increasing temperature from $0^{\circ} \mathrm{C}$ to $40^{\circ} \mathrm{C}$. The conversion was slightly constant at maximum range of $40-60^{\circ} \mathrm{C}(95.1-$ $95.9 \%)$ before dropping at $70^{\circ} \mathrm{C}(94.8 \%)$. This is probably because beyond a critical temperature, the lipase may have been deactivated. The results is similar in the findings by most reviewed papers that Novozym 435 was optimally used at $40^{\circ} \mathrm{C}$ to $60^{\circ} \mathrm{C}$ (Bourg-Garros et al. 1998; Lozano et al. 2003). The conversion decreased slightly after $60^{\circ} \mathrm{C}$ probably caused by the vibration and movement of the enzyme molecule, which would affect the hydrogen bonds and other bonds in the lipase structure. Hence, the enzyme molecule will unfold and alter its tertiary and quaternary structure or globular structure (three-dimensional conformation). Consequently the catalytic power of lipase will be reduced, because denaturation process has occurred. At high temperature $\left(50-60^{\circ} \mathrm{C}\right)$, a higher water evaporation rate may shift the position of the equilibrium to the product side and increases the yield (Chen et al. 1995). It also promotes collisions between enzyme and substrate molecules to result in accelerated rates of reaction. According to Carta et al. (1991) immobilisation on lipase will alter its sensitivity to temperature. Change in the reaction temperature can affect the activity and stability of the enzymes and thus the rates of reaction (McGilvery and Goldstein, 1983).

\section{Effect of amount of enzyme}

From an applied point of reaction, the substrate concentration should be as high as possible to obtain a 
higher degree of esterification. Simultaneously, the amount of immobilised enzyme used should be as low as necessary to obtain the desired product (Kuan et al. 2001). The influence of varying amount of enzyme on the esterification reaction of oleic acid and oleyl alcohol was shown in Figure 4. The percentage conversion had increased from 0.1 $\mathrm{g}(93.5 \%)$ to $0.4 \mathrm{~g}(95.4 \%)$ and kept constant when the amount of enzyme used was about $0.5 \mathrm{~g}(95.1 \%)$. Amount of enzyme at $0.2 \mathrm{~g}(95.2 \%)$ to $0.4 \mathrm{~g}(95.4 \%)$ was sufficient to catalyse this esterification reaction. The excess enzyme did not contribute to the increase in the percentage conversion. This is also similar with what was reported by Torres and Otero, (2001) that an excess of enzyme did not increase in percentage conversion and sometime it would decrease the yield of the product. At saturation point, all the substrates are bound to the enzyme and added enzyme molecule could not find any substrate to serve as a reactant. In esterification reaction, the amount of enzyme will influence the total reaction time, which is required to achieve desired conversion (Bloomer et al. 1992). According to Aracil et al. (1993) the most significant main effect in enzymatic esterification reaction is the initial catalyst concentration.

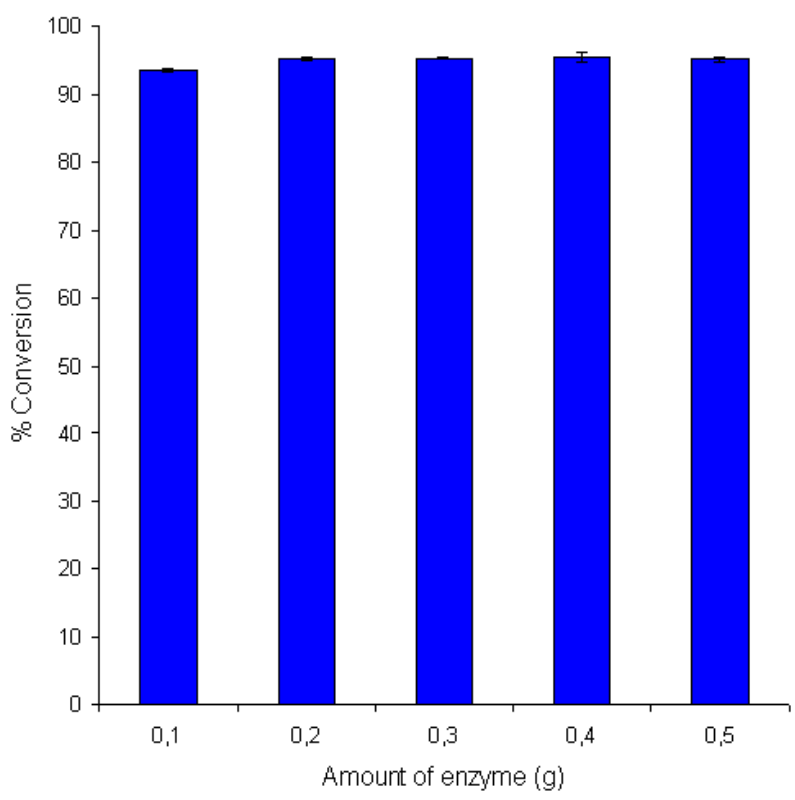

Figure 4. Effect of amount of enzyme on the synthesis of oleyl oleate. Reaction condition: reaction time, $60 \mathrm{~min}$; temperature, $37^{\circ} \mathrm{C}$; molar ratio of substrate (mmol oleyl alcohol/mmol oleic acid), 2:1; and agitation speed of $150 \mathrm{rpm}$.

\section{Effect of molar ratio of substrates}

Relative proportions of the various substrates in a reaction mixture define the physical and chemical properties of a reaction system. High acylation yields can be achieved with high substrate concentrations in the reaction media (Bloomer et al. 1992). The effect of molar ratio of substrates on the esterification reaction is shown in Figure
5. The optimal molar ratio ( $\mathrm{mmol}$ oleyl alcohol/ $\mathrm{mmol}$ oleic acid) was 2:1 (97.2\%). Increasing the mole ratio of oleyl alcohol to oleic acid beyond this (molar ratio $=2: 1$ ) would decrease the esterification activity. This observation may reflect the ability of the excess oleyl alcohol to distort the essential water layer from enzyme. At the same time, the excess of oleyl alcohol will hinder the interaction frequency between substrate and lipases (Kanasawud et al. 1992; Claon and Akoh, 1994). This is may be due to the presence of high substrates concentration, the viscosity of the reaction mixture surrounding the enzyme molecule may be increased due to the increase in the alcohol leading to ineffective mixing of reactants and subsequent reduction in reaction rate (Erbeldinger et al. 1998). This is contrary to what was reported by Chen et al. 1995. The optimal molar ratio to produce oleyl oleate was $1: 1$. The percentage yield of wax ester at higher molar ratio was relatively lower which was due to the presence of high amount of oleyl alcohol instead of the solvent. Oleyl alcohol has a higher density than hexane, thus the interaction of the substrates and the enzyme may be inhibited.

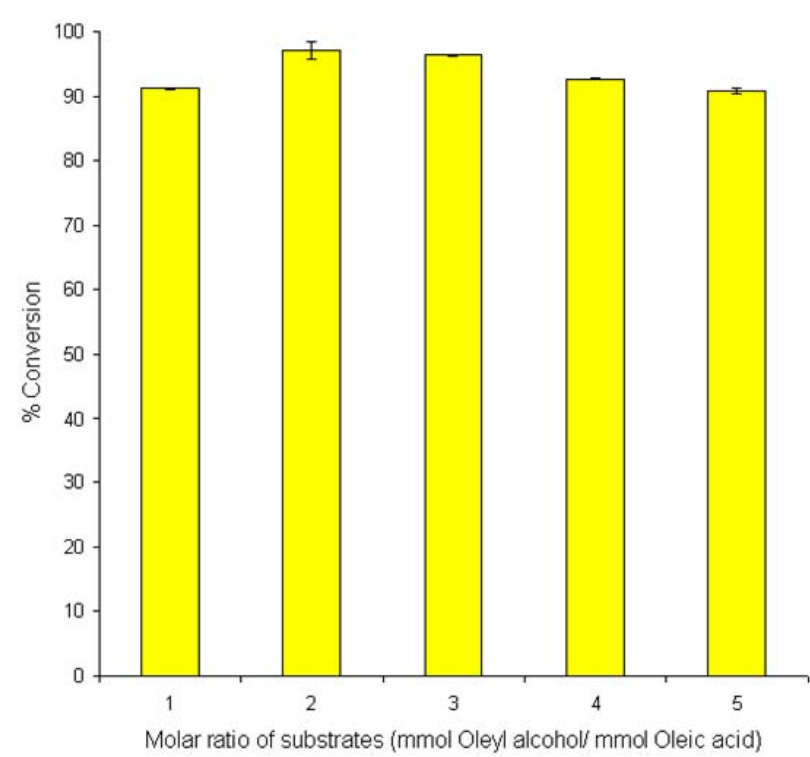

Figure 5. Effect of molar ratio of substrate on the synthesis of oleyl oleate. Reaction condition: reaction time, $60 \mathrm{~min}$; temperature, $37^{\circ} \mathrm{C}$; amount of enzyme, $0.3 \mathrm{~g}$; and agitation speed of $150 \mathrm{rpm}$.

\section{Effect of heat and organic on enzyme stability}

As shown in Figure 6, percentage yield of more than $90 \%$ was achieved although the enzyme was heated at $50^{\circ} \mathrm{C}$ for $60 \mathrm{~min}$ in the oven before it was used for esterification reaction. Incubation in hexane at $50^{\circ} \mathrm{C}$ for $60 \mathrm{~min}$, which was the solvent of choice for the esterification reaction, also did not have any deleterious effect on the enzyme activity. This is mainly attributed to enzyme immobilisation, where enzyme acquires greater resistance toward thermal inactivation (Yee et al. 1997). A similar finding was reported by Ramamurthy and McCurdy, (1994) for their 
work on lipase-catalysed esterification of oleic acid and methanol in hexane.

\section{Effect of enzyme reusability}

The ability of immobilised lipase to retain its synthetic activity during recycling was examined by several workers (Liu and Shaw, 1995; Sellapan and Akoh, 2000; Zhang et al. 2000).In our work, the retention of the Novozym 435 activity after repeated use was assessed in term of \% conversion of oleyl oleate at the end of each cycle. Figure 7 demonstrates the reusability of Novozym 435 on a smallscale by using screw-capped vials. Novozym 435 retained high activity even after 9 uses $(91.9 \%)$. The stability may be due to immobilisation and low water content. Water content plays an important role in enzyme stability, as water is responsible for the internal structural flexibility and for heat-induced inactivation (Sellapan and Akoh, 2000). However, the percentage conversion was decreased from $90 \%$ to $83 \%$ at 13 cycles.

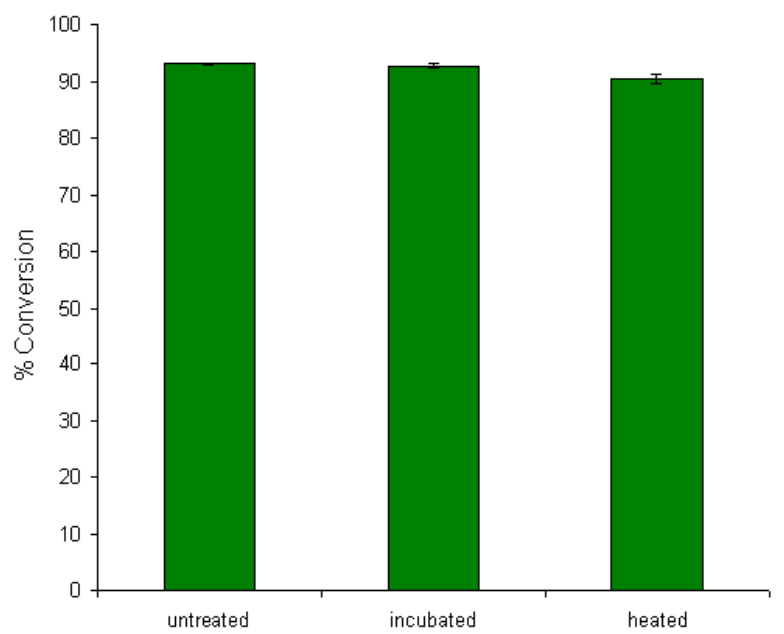

Figure 6. Effect of heat of enzyme stability on the synthesis of oleyl oleate. Reaction condition: reaction time, $60 \mathrm{~min}$; temperature, $37^{\circ} \mathrm{C}$, molar ratio of substrate (mmol oleyl alcohol/mmol oleic acid), 2:1; amount of enzyme, $0.3 \mathrm{~g}$; and agitation speed of $150 \mathrm{rpm}$.

\section{CONCLUDING REMARKS}

Five parameters were chosen to optimise the synthesis of oleyl oleate, namely reaction time, temperature, various organic solvents, molar ratio of substrates and amount of enzyme. The reusability and stability of Novozym 435 on heat were also studied in term of $\%$ conversion. The optimum yield of products $(>90 \%)$ was obtained within 5 min, temperature between $40^{\circ} \mathrm{C}$ to $50^{\circ} \mathrm{C}$, organic solvents with $\log \mathrm{P} \geq 3.5$, molar ratio of $2: 1$ and amount of enzyme of 0.2-0.4 g. Novozym 435 was also stable in the presence of heat and organic solvent and the activity was maintained at $>90 \%$ up to 9 cycles. This work suggests that oleyl oleate, a liquid wax ester can be produced at a very high yield and in a short period by esterification of oleic acid and oleyl alcohol, using immobilised lipase from Candida antartica (Novozym 435). The high percentage conversion is also essential for possible large scale synthesis.

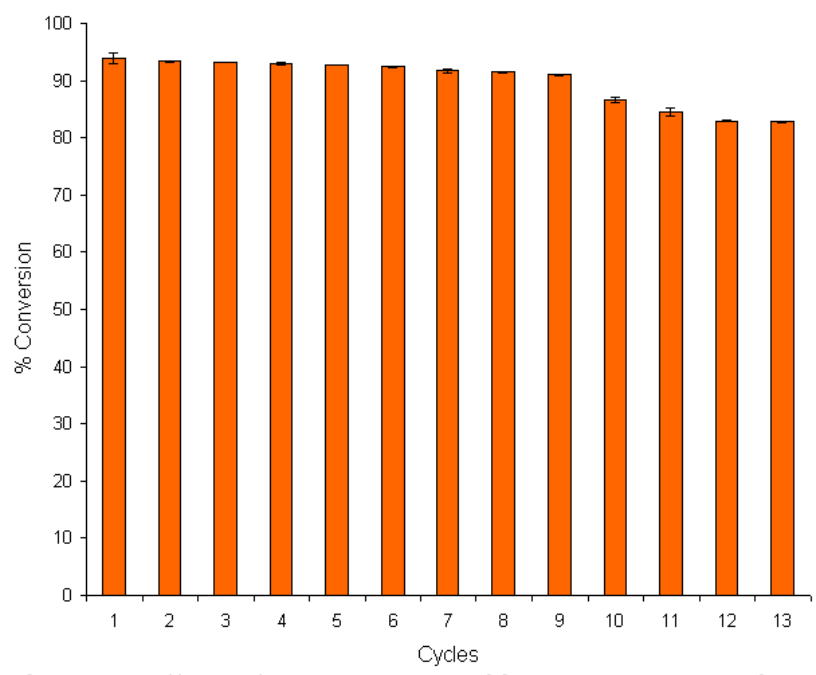

Figure 7. Effect of enzyme reusability on the synthesis of oleyl oleate. Reaction condition: reaction time, $60 \mathrm{~min}$; temperature, $37^{\circ} \mathrm{C}$; molar ratio of substrate (mmol oleyl alcohol $/ \mathrm{mmol}$ oleic acid), 2:1; amount of enzyme, $0.3 \mathrm{~g}$; and agitation speed of $150 \mathrm{rpm}$.

\section{REFERENCES}

AKOH, C.C.; COPPER, C. and NWOSU, C.V. Lipase Gcatalyzed synthesis of monoglycerides in organic solvent and analysis by HPLC. Journal of the American Oil Chemists' Society, 1992, vol. 69, no. 9, p. 257-260.

ARACIL, J.; GARCIA, T. and MARTINEZ, M. Enzymatic synthesis of an analogue of jojoba oil: Optimisation by statistical analysis. Enzyme and Microbial Technology, 1993, vol. 15, no. 7, p. 607-611.

AWANG, Roila; BASRI, Mahiran; AHMAD, Salmiah and SALLEH, Abu Bakar. Enzyme-catalyzed synthesis and characterization of octyl dihydroxystearate from palmbased dihydroxystearic acid. Journal of Oleo Science, 2003, vol. 52, no. 1, p. 7-14.

BLOOMER, S.; ADLERCREUTZ, P. and MATTIASSON, B. Facile synthesis of fatty acid esters in high yields. Enzyme and Microbial Technology, July 1992, vol. 14, no. 7, p. 546-552.

BOURG-GARROS, S.; RAZAFINDRAMBOA, N. and PAVIA, A. A. Optimisation of lipase-catalyzed synthesis of (z)-3-hexen-1-yl acetate by direct esterification in hexane and solvent-free medium. Enzyme and Microbial Technology, March 1998, vol. 22, no. 4, p. 240-245.

CARTA, Giorgio; GAINER, John L. and BENTON, Alan H. Enzymatic synthesis of esters using an immobilised lipase. Biotechnology and Bioengineering, 1991, vol. 37, 
no. 11, p. 1004-1009.

CLAON, P.A. and AKOH, C.C. Enzymatic synthesis of geranyl acetate in n-hexane with Candida antartica lipase. Journal of the American Oil Chemists' Society, 1994, vol. 71, no. 11, p. 1177-1182.

CHEN, H. P.; HSIOU, K. F. and WANG, K. T. Regioselectivity enhancement by partial purification of lipase from Aspergillus niger. Biotechnology Letters, 1995, vol. 17, no. 3, p. 305-308.

DE, B.K.; BHATTACHRYYA, D.K. and BANDHU, C. Enzymatic synthesis of fatty alcohol esters by alcoholysis. Journal of the American Oil Chemists' Society, April 1999, vol. 76, no. 4, p. 451-453.

DECAGNY, B.S.; JAN, S.; VUILLEMARD, J.C.; SARAZIN, C.; SEGUIN, J.P.; GOSSELIN, C.; BARBOTIN, J.N.; and ERGAN, F. Synthesis of wax ester through triolein alcoholysis: Choice of the lipase and study of the mechanism. Enzyme and Microbial Technology, May 1998,vol. 22, no. 7, p. 578-582.

ERBELDINGER, Markus; NI, Xiongwei and HALLING, Peter J. Enzymatic synthesis with mainly undissolved substrates at very high concentrations. Enzyme and Microbial Technology, July 1998, vol. 23, no. 1-2, p. 141148.

FACIOLI, Nara Lucia and BARRERA-ARELLANO, Daniel. Optimisation of enzymatic esterification of soybean oil deoderiser distillate. Journal of the Science of Food and Agriculture, 2001,vol. 81, no. 12, p. 1193-1198.

GILLIES, B.; YAMAZAKI, H. and ARMSTRONG, D. W. Production of flavour esters by immobilised lipase. Biotechnology Letters, 1987, vol. 9, p. 709-719.

GOMA-DONCESCU, N. and LEGOY, M. D. An original transesterification route for fatty ester production from vegetable oils in a solvent-free system. Journal of the American Oil Chemists' Society, 1997, vol. 74, no. 9, p. 1137-1143.

HARI KRISHNA, S.; MANOHAR, B.; DIVAKAR, S. and KARANTH, N.G. Lipase-catalyzed synthesis of isoamyl butyrate: optimisation by response surface methodology. Journal of the American Oil Chemists' Society, December 1999, vol. 76, p. 1483-1488.

HARI KRISHNA, S.; MANOHAR, B.; DIVAKAR, S.; PRAPULLA, S.G. and KARANTH, N.G. Optimisation of isoamyl acetate production by using immobilised lipase from Mucor meihei by response surface methodology. Enzyme and Microbial Technology, February 2000, vol. 26, no. 2-4, p. 131-136.

HARI KRISHNA, S.; SATTUR, A. P. and KARANTH,
N.G. Lipase-catalyzed synthesis of isoamyl isobutyrateoptimisation using a central composite rotatable design. Process Biochemistry, 2001, vol. 37, no. 1, p. 9-16.

KANASAWUD, Pawinee; PHUTRAKUL, Suree; BLOOMER, Scott; ADLERCEUTZ, Patrick and MATTIASSON, Bo. Triglyceride interesterification by lipases 3. Alcoholysis of pure triglycerides. Enzyme and Microbial Technology, December 1992, vol. 14, no. 12, p. 959-965.

KLIBANOV, Alexander M. Why are enzymes less active in organic solvents than in water? Trends Biotechnology, March 1997, vol. 15, no. 3, p. 97-101.

KUAN, Ju Liu; ALHINDRA, Nag and SHAW, Jei-Fu. Lipase-catalyzed synthesis of fatty acid diethanolamides. Journal of Agriculture and Food Chemistry, November 2001, vol. 49 , no. 12 , p. $5761-5764$.

LANGRAND, G.; TRANTAPHYLIDES, C. and BARATTI, J. Lipase-catalyzed formation of flavor esters. Biotechnology Letters, 1988, vol. 10, no. 8, p. 549-554.

LIU, K. J. and SHAW, J. F. Synthesis of propylene glycol monoesters of docosahexaenoic acid and eicosapentaenoic acid by lipase-catalyzed esterification in organic solvents. Journal of the American Oil Chemists' Society, 1995, vol. 72 , no. 11 , p. $1271-1274$.

LOZANO, P.; VILLORA, G.; GOMEZ, D.; GAYO, A. B.; SANCHEZ-CONESA, J. A.; RUBIO, M. and IBORRA, J.L. Membrane reactor with immobilised Candica antartica lipase B for ester synthesis in supercritical carbon dioxide. Journal of Supercritical Fluids, April 2004, vol. 29, no. 12, p. 121-128.

LOZANO, P.; DE DIEGO, Teresa; CARRIE, Daniel; VAULTIER, Michel and IBORRA, José. Enzymatic ester synthesis in ionic liquids. Journal of Molecular Catalysis B: Enzymatic, January 2003, vol. 21, no. 1-2, p. 9-13.

MCGILVERY, R.W. and GOLDSTEIN, G.W. Rates of enzymatic reaction, In: Biochemistry: A Functional Approach. 3rd Edition, Philadelphia, London, Toronto Mexico City and Tokyo; W. B. Saunders Company, 1983, p. 296-307.

MUKERJEE, Kumar D. and KIEWITT, Irmgard. Preparation of esters resembling natural waxes by lipasecatalyzed reactions. Journal of Agriculture and Food Chemistry, 1988, vol. 36, no. 6, p. 1333-1336.

PETER, T.R and ROBERT, B. Beeswax through the ages. Personal care, October 2001, vol. 10, p. 27-31.

PRAPULLA, S.G.; KARANTH, N.G.; ENGEL, K.H. and TRESSEL, R. Production of 6-pentyl-a-pyrone by Trichoderma viridian. Journal of Flavor Fragrance, 1992, vol. 7, p. 231-234. 
RAMAMURTHY, S. and MCCURDY, A.R. Lipasecatalyzed esterification of oleic acid and methanol in hexane - A kinetic study. Journal of the American Oil Chemists' Society, 1994,vol. 71, no. 9, p. 927.

SELLAPAN, Subramani and AKOH, Casimir C. Enzymatic acidolysis of tristearin with lauric and oleic acid to produce coating lipids. Journal of the American Oil Chemists' Society, November 2000, vol. 77, no. 11, p. 1127-1133.

TORRES, Carlos and Otero, Cristina. Part III. Direct enzymatic esterification of lactic acid with fatty acids. Enzyme and Microbial Technology, 2001, vol. 29, no. 1, p. 3-12.

VIRTO, C. and ADLERCREUZ, P. Lysophophatidylcholine synthesis with Candida antartica lipase.Enzyme and Microbial Technology, 2000, vol. 26, no. 8 , p. 630-635.

WILLING, A. Oleochemical esters-environmentally compatible raw materials for oils and lubricants from renewable resources. European Journal of Lipid Science and Technology, 1996, vol. 101, p. 192-197.

YEE, Lisa N.; AKOH, Casimir C. and PHILIPS, S.G. Lipase PS-catalyzed transesterification of citronellyl butyrate and geranyl caproate; effect of reaction parameters. Journal of the American Oil Chemists' Society, March 1997,vol. 74, p. 255-260.

ZHANG, Hong; XU, Xuebing; MU, Huiling; NILSSON, Jorgen; ADLER-NISSEN, Jens and HOY, Carl-Erik. Lipozyme IM catalysed interesterification for the production of margarine fats in a $1 \mathrm{Kg}$ scale stirred tank reactor. European Journal of Lipid Science and Technology, 2000, vol. 102, no. 6, p. 411-418. 